Symbols in the Ukrainian Public Discourse (Analysis of Presidential Speeches on the Occasion of Constitution Day)

Author(s): Solomiia Kryvenko

Source: Kyiv-Mohyla Law and Politics Journal 7 (2021): 109-127

Published by: National University of Kyiv-Mohyla Academy

http://kmlpj.ukma.edu.ua/ 


\title{
Symbols in the Ukrainian Public Discourse (Analysis of Presidential Speeches on the Occasion of Constitution Day)
}

\author{
Solomiia Kryvenko \\ Assistant Professor \\ Ivan Franko National University of Lviv / Ukrainian Catholic University, Ukraine
}

\begin{abstract}
This article develops the understanding of symbols as a certain type of signs, the meaning of which is established by agreement or habit. There is an opinion that symbols in public discourse are a reflection of values and anti-values of the society, which are formed in the process of mass communication. This article identifies the main features of the characters, including emotional engagement, attachment to a particular act of communication, as well informativeness. The types of meaning are determined, and the mechanism of nomination is explained. The article reveals the concept of semantic competition. M. Edelman's opinion that value structures can be divided into mono-, bi- and multimodal - depending on the number of values assigned to key symbols.

The presidential speeches delivered before the Ukrainian Constitution Day in 2017-2O2O were analyzed in this article. Thanks to the content analysis of emotionally colored words, the symbols, which are characteristic for the speeches of P. Poroshenko and V.Zelensky, were identified focusing both on similarities and differences of Ukrainian values and anti-values. This article analyzes the nominations used by speakers to give meaning to key symbols. Aspects of semantic competition of the key symbols are defined here as well.

It was revealed that during the tenure of President Poroshenko, other symbols circulated mostly in the Ukrainian public discourse than those during the presidency of V.Zelensky. Among the common key values for both presidents, we can find "Constitution," "Constitution Day" and "freedom". There is a semantic competition in their use. Both presidents underline the negative meaning of the term "parliamentary immunity."

Poroshenko expresses the threat using symbols such as "Russian aggressor", "fifth column," "corruption," "Russian Empire" and "war." On the other hand, V. Zelensky does not use symbols of external threat. It was found that the value structure formed by Poroshenko's speeches showed signs of bimodality, and the one created by V. Zelensky's speeches - multimodality.
\end{abstract}

Key Words: discourse analysis, public discourse, symbols, semantics, media analytics, mass communication. 


\section{Introduction}

Symbols inherent in mass communication and public discourse are the object of study of psycholinguistics, which is an interdisciplinary approach to the study of texts. Presidential speeches are one of the most important type of material for identifying public values. They reflect the cultural and economic orientations of the political leader and his supporters, as well as dynamics of public opinion. Speech analysis makes it possible to identify frameworks, metaphors, symbols and cultural codes that the mass audience utilizes in their thinking process.

In the texts devoted to the study of symbols in political discourse, making their way in recent years to specialized publications, we can distinguish three categories of research:

1. identifying the semantic meaning of concepts and concepts that are relevant to the policy: "Dynamics of the Semantic Content of the Word Freedom" (BubnovaI., Kazachenko O., 2018), "Psycholinguistic Aspects of the Semantic Field of the Concept "War" in Modern Media Space" (Krylova-Grek Y., 2018); "Transformation of the Concept "Refugee" in Ukrainian and German Linguocultures (Case Study of Psycholinguistic Analysis)" (Milio, 2018); "Stimulus "Ukraine" and Associative-Semantic Field of Students' Mental Lexicons" (Hrukach V, Tkachenko, Solovyova, 2019), "Those are not my words": Evasion and metalingual accountability in political scandal talk" (Chovanec, 202O), "Humorous and ironic readers' comments to a politician's post on Facebook: The case of Miri Regev" (Hirsch, 202O);

2. study of language as a tool in a political struggle: "Psycholinguistic Methods of Suggestion Strategies Realization as US Presidents' G. Bush Jr. and B. Obama Conceptual Style Markers" (Kalishchuk, 2018); "Syntactic Rhythm of Political Speeches as a Psycholinguistic Tool of Suggestive Influence" (Martynyuk, Ponikaryova, 2018); "Neuro-Psycholinguistic Study of Political Slogans in Outdoor Advertising" (Maksymenko, Tkach, 2019), "Naming candidates as preemptive discursive practice: The 2016 Taiwan presidential race" (Wei, 2020), "Interruptions and co-construction in the First 2016 Trumpe Clinton US presidential debate” (Jacobsen, 2019);

3. identification of discursive and cultural features of the community: "Psycholinguistic and Sociolinguistic Parameters of UpperClass Ageing Women's Speech" (Tislenkova, Tikhaeva, 2O2O), "The hurting and healing power of words (and grammatical constructions). A cognitive grammar study of the interactive and interpersonal effects of a directive constuction in Polish" (Kochanska, 2018), "Impoliteness, aggression and the moral order" (Parvaresh, Tayebi, 2018), "Globalization, conflict discourse, and Jewish identity in an Israeli Russian-speaking online community" (Perelmutter, 2018), "The use of positively valued adjectives and adverbs in Polish and Estonian casual conversations" (Vainik, Brzozowska, 2019). 
of Presidential Speeches on the Occasion of Constitution Day)

The purpose of this article is to identify symbols (values and anti-values) entering the public space through the speeches of Ukrainian presidents - Petro Poroshenko and Volodymyr Zelensky.

\section{Research methods.}

In order to achieve this goal, we have chosen the methodology of psycholinguistics, which states the existence of a link between collective behavior, the cognitive structures of the individual, and the language used by the community. Psycholinguistic methods have formed the basis for defining the main categories of research - symbols, connotations, and value structures, as well as the semantic connections between the concepts used by presidents.

In order explain the basic concepts, the works of CH. S Peirce (Peirce, 2000), M. Edelman (Edelman, 1965), G. Pocheptsov (Pocheptsov, 2002), A. G. Girnth (Girnth, 2002), and other academicians were used.

The text of the speeches of the Ukrainian Presidents, delivered on the occasion of Constitution Day in 2017-202O, became the material of the research. Comparative analysis was created in order to compare the symbols used in the speeches of P. Poroshenko (2017 and 2018) and V. Zelensky (2019 and 2020). The value of symbols was determined based on nominations and semantic connections in the texts. This made it possible to divide the symbols into "values" and "anti-values". Semantic comparison of nominations made it possible to identify semantic competition.

\section{Literature review}

According to the American philosopher, Charles Sanders Peirce,

a symbol is one of the types of signs. A sign can be considered a certain object, action or phenomenon that can be perceived by a person (it can be seen, heard, realized, etc.) and provokes, in the mind of a certain interpretant, an association with another object or phenomenon. (Peirce, 2000, 171).

The interpretant is a certain image that is created in the human mind as a result of perception of a sign. The philosopher Ludwig Wittgenstein, in his work "Logical and Philosophical Treatise," remarks:

"What, in fact, is that appears in front of us when we are trying to understand a word?" Doesn't it look like a picture” (Wittgenstein, 1995, 144).

That is the sign, the interpretant, and the object of reality. These are the three elements of the same process of understanding signification. 
In his works, Ch. P. Peirce, offers several classifications of signs, including their division into icons, indexes, and symbols. Icons are signs similar to the object they represent (photograph, make-up, schematic). Indexes are signs that are physically related to their objects; they arise as a result of an interaction, and the interpreting mind notices this connection after its occurrence (traces in the snow; an exclamation that stimulates action, etc.). Instead, the symbol is associated with its object by an idea inherent in the mind itself (Peirce, 2000, 216). That is, to understand a symbol, a person must already have some experience of its interpretation.

The scholar follows the concept of "symbol" from the ancient "throw into one", which was used in concluding a contract or agreement (Peirce, 2000, 215-216). Aristotle calls the noun a "symbol", i. e. a conventional sign. In Greek, watch fire is a "symbol," i. e. a predetermined signal; the flag or banner is a "symbol", the password is a "symbol", the icon is a "symbol;" Church doctrine is called a "symbol" because it is a kind of symbol or Shibbolet... Moreover, a "symbol" also denominated any expression of feeling (Pierce, 2000, 215-216).

Thus, a symbol is a type of sign, the meaning of which (to the interpretant, which is created in the mind of the recipient) is to the result of any prior knowledge of the addressee, their already formed habit or previously stolen agreement.

In general, all nouns can be considered symbols, yet they acquire special significance once they enter the ideological vocabulary. This happens when the initiators of mass communication publicly use certain words to inform or persuade the mass audience. Then the audience begins to ascribe a positive or negative meaning to words (phrases). They begin to reflect public values and anti-values, cause approval or indignation, so they are called words-symbols, "key symbols" (G. Laswell) or fundamental tokens (Girnth, $2002,52)$. According to G. Lasswell, key symbols are common vocabulary inherent in both private and public communication (Lasswell, 1965, 12). The scholar notes that in the United States, such words-symbols include "rights," "freedom," "democracy" and "equality around the corner" (Lasswell, 1965, 13). According to the scientist, their main task is to impose the same attitude to reality — from the highest leader to the humble citizen.

Murray Edelman, an American scholar, in The Symbolic Uses of Politics, notes that as soon as a term becomes a means of expressing group interests, it ceases to be descriptive and becomes only evocative. M. Edelman quotes Rupert Crawshay-Williams:

"When one speaks of 'state control' and 'private enterprise,' and the other of 'private control' and 'state enterprise,' we learn nothing about political economy, but we do learn about group values with which everyone identifies himself" (Edelman, 1965, 125).

Formal categories, which become slogans of political parties, appeals of public leaders, demands of protesters, as well as headlines - are socially significant symbols. 
of Presidential Speeches on the Occasion of Constitution Day)

"They tell us about the prevailing values in culture ... The fact that these names provoke a vision of utopia or fear of destruction among a large number of people, indicates their potential as political symbols" (Edelman, 1965, 161).

Words-symbols provoke an emotional reaction of the mass public. The connotative (emotional and evaluative) component becomes the basis for M. Edelman to divide symbols in public discourse into reference and condensation. According to the scientist, references are an economical way to denote objects, elements of objects or situations - they will be read equally by different people. These symbols help to think logically about the situation.

"These include, in particular, statistics on accidents at work and cost figures, contracts" (Edelman, 1965, 6).

They are devoid of subjective evaluation.

Instead, condensation symbols, which are the second type, evoke an emotional reaction.

"They are condensed into one symbolic event, a sign or act of patriotic pride, memories of past glory or humiliation, a promise of future greatness" (Edelman, 1965, 6).

According to the scientist, the symbolic potential in politics also has a setting (environment in which the action takes place), the personality of the leader and his behavior, rituals - they also affect the audience and correspond to the main features of symbols (even though not expressed in words). M. Edelman notes that almost every political action that is controversial or considered very important is a symbol of condensation as it causes a silent or violent reaction of the masses.

"The significance of an action depends only in part (or not at all) on objective consequences that the public cannot be aware of; the value is determined only by the psychological needs of respondents." (Edelman, 1965, 7-8)

According to the scholar, the psychological need of the audience is reduced to two key functions of symbols - they are either to calm them down or indicate a threat (Edelman, 1965, 13).

In addition to emotional saturation, the community vocabulary reflects beliefs of past, magical superstitions and mystical allusions (Edelman, 1965, 120). The archaic interpretations of certain symbols "contract or habit" are inherent in any language, so that words-values are not always translatable or result in a similar reply among other 
audiences. According to M. Edelman, the meaning depends more or less on the values established by the community:

"It would be difficult in another language to express the differences we feel between "to kill" and "to murder" for a simple reason: the basis of legal philosophy, which determines our way of using words, is not common to all communities" (Edelman, 1965, 120).

Value and the emotional (emotional or connotative) dimensions of symbolic meaning are supplemented by an informative component. After all, the mass public is deprived of the opportunity to directly perceive the real situation and learn about it through symbols.

"For most people, politics is mostly a series of pictures in their head, filled with television news, newspapers, magazines, and discussions" (Edelman, 1965, 5).

With symbols at their disposal, a group of people who are unable to analyze a complex reality manage to adapt to it - through stereotyping, simplification and reassurance (Edelman, 1965, 40).

It is important for the author of mass communication to control how the audience will perceive a certain symbol, which is usually devoid of a single meaning. In Lady Victoria Welby's work "What is meaning," there are three levels. The first level is the meaning used in a particular act of speech. The second level of meaning is the total sum of all conditional predictions for which the person using the word intends to take responsibility. In addition to the consequences that a person can predict,

"there is still a wide ocean of unpredictable consequences that judgments generate... and the sum of these consequences is the third class of values" (Peirce, 2000, 225)

One of the mechanisms to control the meaning of a symbol (its interpreter) in the mass consciousness is to resort to nominations. A nomination is a linguistic action, a communicative definition of an object, which reflects the attitude of a politician to it (Girnth, 2002, 57). Thus, the author of a public broadcast expresses approval or indignation over certain phenomena or events. The result of the nomination is a change in the collective consciousness: a modification (change) of the attitude to a certain object, a polarization of the attitude or an affirmation (fixation) (Girnth, 2002, 57).

Given that each speaker in public space can resort to their nominations, the symbol can be endowed with several meanings at the same time. In this case, there is semantic competition (J. Klein), ideological polysemy (W. Dickman) or semantic variability (J. Strauss, G. Tsifonum) (Girnth, 2002, 52). In particular, G. Pocheptsov, 
of Presidential Speeches on the Occasion of Constitution Day)

when analyzing the process of struggle for symbol, notes that the symbols of different systems cannot coexist:

"Democratic symbols fight with the same zeal with the socialist symbols, as happened before with themselves" (Pocheptsov, 2002, 141).

M. Schröter identifies two aspects of semantic competition: competition for descriptive meaning (definition) and competition for deontic meaning (evaluation) (Schröter, 2009, 27). G. Girnth distinguishes three planes of competition: denotative (definition), evolutionary and deontic (the last two cover the concept of connotation) (Girnth, 2002, 51). For example, the denotation for the symbol "democracy" would be "form of government." An evolutionary feature suggests that democracy is a positive phenomenon. The deontic aspect explains whether the thing in question is necessary or can be dispensed with, i. e. democracy is an ideal to which one must strive (Girnth, 2002, 51; Krivenko, 2016, 70).

Each culture can be described by a number of key values (and anti-values) used by its representatives. If the majority defines symbols-values in the same way, then, according to M. Edelman, a unimodal (monomodal) structure of values prevails in this society.

"This is the type of value structures to which the American population has been closest for most of its history. There is a strong consensus here on the fundamental directions of the government" (Edelman, 1965, 176).

According to him, monomodal (unimodal) systems predetermine that political parties and interest groups will move in the same direction, which is why the public develops non-criticism. The unimodal structure exists without significant stress on norms but creates the conditions for the emergence of symptoms of mass society.

Where there is no common understanding of key values in society, it is a bimodal or multimodal structure of values. In the bimodal system, public values are polarized into two enemy camps, and in the multimodal system, they are scattered. According to M. Edelman, the presence of a bimodal structure of values will mean maximum tension in society because those who do not share each other's values will become their enemies.

Multimodal scattering means "talking freely about the possibilities of alternatives" when the majority of the population sees advantages in all aspects of argumentation. The danger of this system is that, despite the critical nature of society, a minimal proportion of the population will remain frozen in narrow classes or other fixed groups, and the vast majority are marginals seeking synthesis (theses and antitheses) (Edelman, 1965, 176). 


\section{Research procedure.}

In the process of content analysis of speeches dedicated to Constitution Day delivered by the Presidents of Ukraine - Petro Poroshenko and Volodymyr Zelensky - in 20172020, symbols were used to understand nouns and phrases that each author gave a positive or negative emotional assessment (see Tables 1 and 2).

Positive connotation was determined by combining concepts with such parts of speech as:

1. possessive pronoun "our," - "our clearly calibrated European course" (Poroshenko, 2018); "Our Constitution" (Zelensky, 2020);

2. adjectives: "historical," "great," “important," “main," "strong," "constitutional," "most democratic," "progressive;" "wonderful," "magical:" "historical document ... The Constitution of Pylyp Orlyk" (Poroshenko, 2018), "near the monument of the great Ukrainian Hetman Pylyp Orlyk" (Poroshenko, 2017), "the great Mazepa" (Poroshenko, 2017), "Another important change to the Constitution is the reflection in the Constitution of Crimea" (Poroshenko, 2018), "a strong legal foundation" (Zelensky, 2020), "one of the oldest constitutional documents in the history of mankind" (Poroshenko, 2017), The Basic Law of our state, which is still considered one of the most democratic in the world (Poroshenko, 2017), "one of the most progressive" (Poroshenko, 2017), "Ukraine is incredibly beautiful and charming" (Zelensky, 2020);

3. verbs "protect," "affirm," "respect," "save," "to be proud," "hope," "honor," "consolidate," "welcome," "support," "promise”: "Assert our European choice" (Poroshenko, 2017), "respect the law" (Zelensky, 2020), "save Ukraine” (Zelensky, 2020), "we respect the Ukrainian Constitution." (Poroshenko, 2018), "The act that consolidated democracy, consolidated the power of the people" (Poroshenko, 2018), "Congratulations on Constitution Day" (Zelensky, 2019), "focus on the European Union and the North. The Atlantic Alliance is supported by the vast majority of citizens" (Poroshenko, 2018), "Protect every Ukrainian. And it is the constitutional citizen rights that give us a clue how to achieve this" (Zelensky, 2020), "promised to lift parliamentary immunity" (Poroshenko, 2018);

4. verbs in the form of appeals: "write," "join," "tell:" "Make a short video and tell about one of articles of the Constitution of Ukraine," "join the flash mob";

5. (Zelensky, 2019); "Let us be citizens every day" (Zelensky, 202O), "Let us take care of the people around us!" (Zelensky, 2020);

6. noun nominations: "priority," "importance," "protection," "holiday," "goals," "main," "fame," "social value": "The start of the Supreme Court in the judicial system is our main priority" (Poroshenko, 2017), "Over the ages, Ukrainians have understood the importance of equal rights, democracy and responsible government" (Poroshenko, 2017), "protection of the law for their independence, impartiality in making certain court decisions" (Poroshenko, 2018), "when in 1996 the Verkhovna Rada of Ukraine approved the Constitution of an independent state, our Basic Law, it was and still remains a real holiday for us" (Poroshenko, 
2017), "... an amendment that will consolidate our two strategic goals ... This is Ukraine's accession to the European Union and Ukraine's accession to NATO" (Poroshenko, 2018), "the main thing is to receive and respect [the Constitution]" (Zelensky, 2019), "Glory to Ukraine" (Poroshenko, 2017, Poroshenko, 2018), "Man, his/her life and health, honor and dignity, inviolability and security are recognized in Ukraine as the highest social value" (Zelensky, 2019);

7. adverbs: "finally," "in the end," "once and forever," "exactly," "cool:" "Let us finally return to the European home" (Poroshenko, 2017), "once and forever to equate ourselves with the citizens of Ukraine" (Poroshenko, 2017), "it is very cool— to make a Constitution for children" (Zelensky, 2019);

8. modal verbs: "must," "should," "have:" "we must promise ourselves that we will pass on a new country to the next generation (Zelensky, 2020), "what book should every Ukrainian read ... it is the Constitution of Ukraine” (Zelensky, 2019);

9. prepositions: "for" and "to," which express the intention of the author: "to know our Constitution, and most importantly - to abide by and respect it. To do this, I offer the whole country a flash mob" (Zelensky, 2019), "changes to the Constitution to ensure the restoration of justice" (Poroshenko, 2017), "Are we doing enough to hold the title of responsible citizen?" (Zelensky, 2020), "in order to become a successful country, united and the only successful country of successful people" (Poroshenko, 2018);

10. participle: "without waiting," "protecting:" "defending their sovereignty, protecting territorial integrity" (Poroshenko, 2018); through comparison: "we need unity, just like we need the air" (Poroshenko, 2018).

Anti-values were determined through nouns and phrases accompanied by the following parts of speech:

1. verbs “defend against," "loop," "blow up," “repel," "break:" “defend our independence from the Russian aggressor (Poroshenko, 2017), "so that no one would think to loop" (Poroshenko, 2018), "Ukrainian Armed Forces repel the Russian aggressor" (Poroshenko, 2018), "when they are ready to break, virtually or really, anyone who has a different opinion than yours" (Zelensky, 2020);

2. noun nominations: "anachronism," "fifth column," "crisis," "threat," "vaccination against federalization" (Poroshenko, 2018), "willing" to do something contrary to values - more and more willing to question our clearly calibrated European course (Poroshenko, 2018); "The cause of crises and trials" (Poroshenko, 2018); "Threat of revision of the European and Euro-Atlantic strategy" (Poroshenko, 2018);

3. phrase "it is impossible" - "it is impossible to change the Constitution for specific individuals" (Poroshenko, 2018);

4. adverbs: "unfortunately" ("unfortunately, it ended with the loss of Ukraine's independence due to the inability of the then-current elite to consolidate (Poroshenko, 2018)); "Disrespectful" attitude to the Constitution (Poroshenko, 2018); "Unacceptable"; 
5. adjectives: "irresponsible" — "irresponsible politicians paint the need to return to the East" (Poroshenko, 2018);

6. interjection: "Goodbye!" to the Russian Empire" (Poroshenko, 2017);

7. conjunction to + particle "not": "not to look precocious and opportunistic (Poroshenko, 2018).

In addition, values and anti-values are present in oppositions, in the constructions "not ..., but ...." "The country is not aggression and hatred, but mutual respect, freedom and equality", "Respect the law, rather than compete in intelligence how to get around it" (Zelensky, 2020).

\section{Discussion of results.}

After analyzing the speeches, both politicians were found, to a greater or lesser extent, to operate with different symbols (words-values and words-anti-values). In general, Poroshenko uses a larger number of symbols - both positively and negatively connoted, compared to V. Zelensky. In total, in Poroshenko's speeches 26 values and 4 anti-values were identified in 2017 , and 24 and 15 values and anti-values respectively in 2018. V. Zelensky's speeches were allocated 6 values and two anti-values in 2019, and 19 and 4 values and anti-values respectively in 2020 .

Poroshenko gave a positive connotation to the symbols: "deep reforms", "decentralization" and "judicial reform." The speaker called Pylyp Orlyk's Constitution an important part of Ukrainian history, noting the EU and NATO orientation as a necessary component of Ukrainian policy: "European and Euro-Atlantic integration clearly correspond to Ukraine's national interests" (Poroshenko, 2018). None of these symbols were repeated in the speeches of V. Zelensky.

Instead, in his speeches, V. Zelensky chooses the following words-values: "man," "Ukraine," "flash mob" (Zelensky, 2019), "rights," "law," "civil society," “mutual respect," "equality" (Zelensky, 2020). It is worth noting that in 2019, V. Zelensky uses the symbols "flash mob" and "\#myfavoritestattya," which form an association with digital technologies, while Poroshenko adheres to the symbols and setting of the traditional format (in particular, he speaks at the monument dedicated to Pylyp Orlyk).

Among the words which are anti-values specific to each speaker, Poroshenko's speeches highlighted the following: "Russian aggressor," and "corruption" (Poroshenko, 2017), "political elite," "current situation," "change the Constitution for specific individuals," "Threat of revision of European and Euro-Atlantic strategy," "war," "politicians," "fifth column, which undermines unity and external forces helping it" (Poroshenko, 2018). These symbols indicate mainly an external threat.

In the speech of V.Zelensky in 2020, the images of Ukrainians themselves are reflected negatively, 202O). Despite the negative connotation, these symbols maintain a connection between the speaker and the audience (through the pronoun "we"). This also applies to other formulations ("we go to the subway without a mask," "turn on the music at night," "set fire to the grass," "cut our own forest," "ride an overloaded truck"), 
of Presidential Speeches on the Occasion of Constitution Day)

which due to the sensitivity of the key noun to denote value / anti-value, could not be classified as either positively or negatively connoted symbols.

The symbols-values common to both Presidents include: "Constitution Day," "Constitution" and "Freedom." Poroshenko, as well as many experts, both Ukrainian and foreign, say that the Constitution, a document adopted in 1996, as amended in 2004, was assessed as one of the most progressive, most perfect and most democratic legal documents (Poroshenko, 2018). V. Zelensky explained the symbol "Constitution" as follows: "Recently, at the Book Arsenal, journalists asked me: What book do you think every Ukrainian should read? The answer was obvious - it is the Constitution of Ukraine" (Zelensky, 2019).

Poroshenko defines the symbol of "Constitution Day" through the past: "Only 21 year ago, after many hours of battles, on the morning of June 28, 1996, the Verkhovna Rada of Ukraine adopted the Constitution of Ukraine - the Basic Law of our state, which is still considered one of the most democratic in the world." (Poroshenko, 2017). Instead, V. Zelensky in his speech in 2020 , creates an association with the future for the symbol "Constitution Day:" "And especially today, not only on Constitution Day, but also Youth Day, we must promise ourselves that we will pass on a new country to the next generation" (Zelensky, 2020). Thus, there is a semantic competition in the definition of the symbol by the two Presidents.

Poroshenko connects the symbol of "freedom" with the idea of protection: "We defend democracy, defend freedom, defend liberty, assert our European choice" (Poroshenko, 2017). Instead, for V. Zelensky, "freedom" is something that still needs to be achieved: "we must promise ourselves that we will pass on a new country to the next generation. A country not of aggression and hatred, but of mutual respect, freedom and equality" (Zelensky, 2020).

Some of the negatively reflected symbols inherent in the speeches of both heads of state include the term "parliamentary immunity". Poroshenko calls it an "anachronism" (Poroshenko, 2017). On the other hand, V.Zelensky, in order to create a negative connotation, uses irony: "Our national deputies may not take part [in the flash mob]. We already know their favourite article-Article 8o-Inviolability" (Zelensky, 2019). In the above example, "national deputies" are deprived of positive value, designate something, the absence of which makes it possible to manage a flash mob. On the other hand, Poroshenko uses the symbol "national deputies" in combination with the word "necessary:" "And I wanted to thank the Ukrainian Verkhovna Rada for the fact that national deputies gave the necessary constitutional majority" (Poroshenko, 2018). Accordingly, the semantic competition in the deontic aspect can be seen in the perception of the symbol "national deputies".

Poroshenko gives a negative meaning, not to the symbol of "national deputies", but to the symbol of "political elite:" "The political elite of Ukraine, in my opinion, is quite disrespectful and not careful enough with the Constitution" (Poroshenko, 2018), and 100 years ago was incapable of consolidation (Poroshenko, 2018). 
Poroshenko defines two poles of attitude to constitutional changes. Either positively reflected - "strictly follow the procedures for changes to the Constitution" (Poroshenko, 2018), or the desire to "change the constitution for specific individuals" (Poroshenko, 2018) - which was negatively reflected. In comparison, V. Zelensky is inclined to a multimodal explanation of the term "Constitution" as a symbol, i. e. he does not resort to a clear definition: "And what is the Constitution for you? Just a book I've been reading for so long that I don't remember? What rights do I want to exercise and what responsibilities would I prefer not to perform? What do politicians constantly want to change? Is it the legal foundation supporting the state? Or maybe it is easier so? Maybe our Constitution is the source of answers?" (Zelensky, 2020).

Thus, the analysis gives us grounds to claim that during the presidency of P. Poroshenko, the value structure showed signs of bimodality (either we follow the Constitution or not), and for V.Zelensky - multimodality, when there are no clear denotations.

\section{Conclusions.}

Thus, symbols in public discourse are a type of signs that acquire meaning as a result of mass communication. Emotionally highlighted symbols present in the speeches of political leaders reflect the values and anti-values of a particular community and shape their attitude to reality.

The variety of meanings that symbols are given determines the existence of semantic competition. Its presence may indicate the establishment of a bimodal or a multimodal value structure, while the lack of semantic competition creates a monomodal value system. One of the mechanisms to ascribe meaning to symbols is the nomination process.

In the Ukrainian public discourse, other symbols circulated during the presidency of P. Poroshenko than those during the presidency of V.Zelensky. Poroshenko used the following positively connoted symbols: "reforms," "decentralization," "Pylyp Orlyk's Constitution," "the EU and NATO." On the other hand, V. Zelensky chooses the following words-values: "human," "Ukraine," "rights," "law," "civil society" and "respect."

Both presidents attach negative importance to the "parliamentary immunity." Poroshenko expresses the external threat using such symbols as: "Russian aggressor," "fifth column," "Russian Empire," "war," and the internal threat with: "political situation," "corruption" and "politicians." In comparison, V. Zelensky does not use any external threat symbols.

Semantic competition is seen in the following words-values: "Constitution", "Constitution Day" and "freedom." These phrases are common for both presidents. 
Table 1. Symbols in the speeches of Petro Poroshenko.

\begin{tabular}{|c|c|c|c|c|}
\hline & 2017 & 2018 & 2017 & 2018 \\
\hline & + (positively & + & - (negatively & - \\
\hline & connotated) & & connotated) & \\
\hline 1. & Constitution Day & Ukrainian Constitution & Russian aggressor & political elite \\
\hline \multirow[t]{4}{*}{2.} & The basic law & Constitution Day & parliamentary & political system, form of \\
\hline & & & immunity & government, government \\
\hline & & & & to change to adapt to the \\
\hline & & & & current situation \\
\hline \multirow[t]{3}{*}{3} & Mazepa & Pylyp Orlyk, the famous & corruption & to change the \\
\hline & & Ukrainian hetman & & Constitution for specific \\
\hline & & & & individuals \\
\hline \multirow[t]{2}{*}{4.} & Constitution of & democracy & Russian Empire & parliamentary immunity \\
\hline & Ukraine & & & \\
\hline \multirow[t]{4}{*}{$5 \cdot$} & independence & The power of the nation & & the ones willing to \\
\hline & & & & question our well- \\
\hline & & & & adjusted European \\
\hline & & & & course \\
\hline \multirow[t]{7}{*}{6.} & "Pacts and & Pylyp Orlyk's & & Revision of the European \\
\hline & Constitutions & Constitution & & and Euro-Atlantic \\
\hline & of Rights and & & & strategy \\
\hline & Freedoms of the & & & \\
\hline & Zaporizhia Army" & & & \\
\hline & (Constitution of & & & \\
\hline & Pylyp Orlyk) & & & \\
\hline \multirow[t]{3}{*}{$7 \cdot$} & land & The current Basic Law of & & irresponsible politicians \\
\hline & & Ukraine / Constitution & & \\
\hline & & as amended in 2004 & & \\
\hline \multirow[t]{3}{*}{8.} & territorial integrity & the road is open for & & the need to return to the \\
\hline & & three hundred votes in & & East \\
\hline & & the council & & \\
\hline \multirow[t]{4}{*}{10.} & democracy & adhere to the & & loss of Ukraine's \\
\hline & & procedures for & & independence \\
\hline & & amending the & & \\
\hline & & Constitution & & \\
\hline \multirow[t]{2}{*}{11.} & liberty & Strictly follow the Basic & & inability to consolidate \\
\hline & & Law & & \\
\hline \multirow[t]{3}{*}{12.} & victory & Ukraine's accession to & & irresponsible behaviour \\
\hline & & the European Union and & & towards the state and \\
\hline & & & & nation \\
\hline
\end{tabular}




\begin{tabular}{|c|c|c|c|}
\hline 12. & justice & $\begin{array}{l}\text { Ukraine's accession to } \\
\text { NATO }\end{array}$ & Politicians \\
\hline 13. & European choice & $\begin{array}{l}\text { reflected in the } \\
\text { Constitution of Crimea }\end{array}$ & war \\
\hline 14. & deep reforms & $\begin{array}{l}\text { European and Euro-- } \\
\text { Atlantic integration }\end{array}$ & to the Russian aggressor \\
\hline 15 & $\begin{array}{l}\text { amendments to } \\
\text { the Constitution }\end{array}$ & unity & $\begin{array}{l}\text { the fifth column, which } \\
\text { undermines unity and } \\
\text { helpful external forces }\end{array}$ \\
\hline 16. & Impartiality (law) & sovereignty & \\
\hline 17. & Legal certainty & & \\
\hline 18. & equality & territorial integrity & \\
\hline 19. & openness & consolidation & \\
\hline 20. & European Union & $\begin{array}{l}\text { restoration of } \\
\text { sovereignty }\end{array}$ & \\
\hline 21. & $\begin{array}{l}\text { Commencement } \\
\text { of work of the } \\
\text { supreme court in } \\
\text { the judicial system }\end{array}$ & $\begin{array}{l}\text { return of Crimea and } \\
\text { occupied Donbas }\end{array}$ & \\
\hline 22. & $\begin{array}{l}\text { to make the rights } \\
\text { of Ukrainian } \\
\text { citizens equal }\end{array}$ & establishing peace & \\
\hline 23. & $\begin{array}{l}\text { Democratic } \\
\text { system }\end{array}$ & success/development & \\
\hline 24. & $\begin{array}{l}\text { Responsible } \\
\text { government }\end{array}$ & $\begin{array}{l}\text { Successful country of } \\
\text { successful people }\end{array}$ & \\
\hline 25. & visa-free travel & & \\
\hline 26. & future & & \\
\hline
\end{tabular}


of Presidential Speeches on the Occasion of Constitution Day)

Table 2. Symbols in the speeches of Volodymyr Zelensky.

\begin{tabular}{|c|c|c|c|c|}
\hline & 2019 & 2020 & 2019 & 2020 \\
\hline & $\begin{array}{l}+(\text { positively } \\
\text { connotated })\end{array}$ & + & - & - \\
\hline 1. & Constitution Day & Constitution Day & national deputies & $\begin{array}{l}\text { encroach on another } \\
\text { person's rights }\end{array}$ \\
\hline 2. & $\begin{array}{l}\text { Constitution of } \\
\text { Ukraine }\end{array}$ & Constitution & $\begin{array}{l}\text { immunity / } \\
\text { Article 8o of the } \\
\text { Constitution }\end{array}$ & $\begin{array}{l}\text { compete, how to break } \\
\text { [law] it }\end{array}$ \\
\hline 3. & $\begin{array}{l}\text { Human (his/her } \\
\text { life and health, } \\
\text { honor and dignity, } \\
\text { inviolability and } \\
\text { security) }\end{array}$ & $\begin{array}{l}\text { title of responsible } \\
\text { citizen }\end{array}$ & & $\begin{array}{l}\text { ready to kill, virtually or } \\
\text { really, anyone who has } \\
\text { a different opinion than } \\
\text { yours }\end{array}$ \\
\hline 4. & flash mob & Kherson region & & $\begin{array}{l}\text { country of aggression } \\
\text { and hatred }\end{array}$ \\
\hline 5 . & $\begin{array}{l}\text { creating } \\
\text { a constitution } \\
\text { book for the } \\
\text { youngest }\end{array}$ & Ukraine & & \\
\hline 6. & $\begin{array}{l}\text { Be familiar with } \\
\text { our constitution }\end{array}$ & Constitutional rights & & \\
\hline 7. & & each other's rights & & \\
\hline 8. & & law & & \\
\hline 9. & & Constitution & & \\
\hline 10. & & civil society & & \\
\hline 11. & & everyone's rights & & \\
\hline 12. & & every Ukrainian & & \\
\hline 13. & & $\begin{array}{l}\text { a country that everyone } \\
\text { respects }\end{array}$ & & \\
\hline 14. & & new country & & \\
\hline 15. & & mutual respect & & \\
\hline 16. & & liberty & & \\
\hline 17. & & equality & & \\
\hline 18. & & citizen & & \\
\hline 19. & & people around us & & \\
\hline
\end{tabular}




\section{Bibliography}

Bubnova, I. and O. Kazachenko "Dynamics of the Semantic Content of the Word Freedom.” Psycholinguistics, 23, no. 2 (2018): 11-24. https://doi.org/10.5281/ zenodo.1199o99.

Chovanec, J. “"Those are Not My Words”: Evasion and Metalingual Accountability in Political Scandal Talk." Journal of Pragmatics. 158 (2020): 66-79. https://doi. org/10.1016/j.pragma.2020.01.003.

Edelman, M. The Symbolic Uses of Politics. Urbana: University of Illinois Press, 1965.

Girnth, H. Sprache und Sprachverwendung in der Politik: eine Einführung in die linguistische Analyse öffentlich-politischer Kommunikation Tübingen: Niemeyer, $2 \mathrm{O} 2 \mathrm{O}$.

Hirsch, G. “Humorous and Ironic Readers' Comments to a Politician's post on Facebook: The case of Miri Regev." Journal of Pragmatics 164 (2020): 40-53. https://doi. org/10.1016/j.pragma.2020.04.012.

Hrukach, V. and O. Tkachenko. "Stimulus "Ukraine" and Associative-Semantic Field of Students' Mental Lexicons." Psycholinguistics, 26, no. 2 92019): 46-69. https://doi. org/10.31470/2309-1797-2019-26-2-46-69.

Jacobsen, R. R. "Interruptions and Co-construction in the First 2016 Trumpe Clinton US Presidential Debate." Journal of Pragmatics 148 (2019): 71-87. https://doi. org/10.1016/j.pragma.2019.05.019.

Kalishchuk, D. "Psycholinguistic Methods of Suggestion Strategies Realization as US Presidents' G. Bush Jr. and B. Obama Conceptual Style Markers." Psycholinguistics 23, no. 2 (2018): 107-119. https://doi.org/10.5281/zenodo.1199146.

Kochanska, A. "The Hurting and Healing Power of Words (and Grammatical Constructions). A Cognitive Grammar Study of the Interactive and Interpersonal Effects of a Directive Construction in Polish." Journal of Pragmatics 134 (2018):1-14. https://doi.org/10.1016/j.pragma.2018.o6.oo4.

Krylova-Grek, Y. "Psycholinguistic Aspects of the Semantic Field of the Concept "War" in Modern Media Space." Psycholinguistics 23, no. 1 (2018) 175-188. https://doi. org/10.5281/zenodo.1211561.

Kryvenko, S.-V. O. Semantychna paradoksal'nist' politychnoho dyskursu (teoretyko-metodolohichnyj analiz) [Semantical Paradoxicalness of Political Discourse (Theoretical and Methodological Analysis)]. Manuscript. Dysertatsiia na zdobuttia naukovoho stupenia kandydata politychnykh nauk za spetsial'nistiu 23.00.01teoriia ta istoriia politychnoi nauky. - L'vivs'kyj natsional'nyj universytet im. Ivana Franka. L'viv (2016).

Lasswell, H. D. Language of Politics Politics: Studies in Quantitative Semantics. Copyright assigned to the Massachusetts Institute of technology. (1965).

Maksymenko, S. and B. Tkach. (2019). "Neuro-Psycholinguistic Study of Political Slogans in Outdoor Advertising." Psycholinguistics 26, no. 1 (2019): 246-264. https://doi. org/10.31470/2309-1797-2019-26-1-246-264. 
Martynyuk, A. and A. Ponikaryova. "Syntactic Rhythm of Political Speeches as a Psycholinguistic Tool of Suggestive Influence." Psycholinguistics 24, no. 2 (2018): 181-197. https://doi.org/10.31470/2309-1797-2018-24-2-181-197.

Milio, A. "Transformation of the Concept "Refugee" in Ukrainian and German Linguocultures (Case Study of Psycholinguistic Analysis)." Psycholinguistics. 23, no. 2 (2018): 165-179. https://doi.org/10.5281/zenodo.1199173.

Parvaresh, V. and T. Tayebi.(2018). "Impoliteness, Aggression and the Moral Order." Journal of Pragmatics 132 (2018): 91-107. https://doi.org/10.1016/j.pragma.2018.05.010.

Peirce, C. S. Ledy Uelby. "Chto takoe znachenye [Lady Welby. What is Meaning]." In Izbrannye filosofskie proizvedenyia, transl. K. Holubovych, K. Chukhrukydze, T. Dmytryeva, 223-233. Moscow: Lohos, 2000.

Peirce, C. S. "O znakakh i kategoriyakh [About Signs and Categories]." In Izbrannye filosofskie proizvedenyia, transl. K. Holubovych, K. Chukhrukydze, T. Dmytryeva, 162-175. Moscow: Lohos, 2000.

Peirce, C. S. "Ikona, indeks i simvol [Icon, Index and Symbol]." In Izbrannye filosofskie proizvedenyia, transl. K. Holubovych, K. Chukhrukydze, T. Dmytryeva, 200-222. Moscow: Lohos, 2000.

Perelmutter, R. "Globalization, Conflict Discourse, and Jewish Identity in an Israeli Russian-speaking Online Community." Journal of Pragmatics 134 (2018): 134-148. https://doi.org/10.1016/j.pragma.2018.03.019.

Pocheptsov, H. Semiotyka [Semiotics]. Moscow: Refl-buk; Kyiv: Vakler, 2002.

Poroshenko, P. (2018). Nam iak povitria potribna iednist': Vystup prezydenta Ukrainy Petra Poroshenka z nahody Dnia Konstytutsii [We Need Unity Like Air: Speech of the President of Ukraine Petro Poroshenko on Constitution Day]. Accessed December 26, 2021. https://ua.112.ua/mnenie/nam-iak-povitria-potribna-iednist-vystup-prezydenta-ukrainy-petra-poroshenka-z-nahody-dnia-konstytutsii-451638. html.

Poroshenko, P. (2017). Vystup z nahody Dnia Konstytutsii (povniy tekst) [Speech on Constitution Day (fulltext)]. Accessed December 26, 2021. https://www.volyn. com.ua/news/79845-vistup-petra-poroshenka-z-nagodi-dnya-konstitutsii-povniytekst.html.

Schröter, M. Vom politischen Gebrauch der Sprache. Wort, Text, Diskurs / Eine Einführung. Frankfurt am Main: Peter Lang Internationaler Verlag der Wissenschaften, 2009.

Tislenkova, I. and V. Tikhaeva. "Psycholinguistic and Sociolinguistic Parameters of UpperClass Ageing Women's Speech." Journal of Psycholinguistic Research 49, no. 1 (2020): 319-334. https://doi.org/10.1007/s10936-o2O-o9692-w.

Vainik, E. and D. Brzozowska. "The Use of Positively Valued Adjectives and Adverbs in Polish and Estonian Casual Conversations." Journal of Pragmatics 153 (2019): 103-115, https://doi.org/10.1016/j.pragma.2019.02.001.

Wei, J. M. "Naming Candidates as Preemptive Discursive Practice: The 2016 Taiwan Presidential Race." Journal of Pragmatics 166 (2020): 84-96. https://doi. org/10.1016/j.pragma.2020.05.012. 
Wittgenstein, L. Tractatus Logico-Philosophicus; Filosofski doslidzhennia [Tractatus Logico-Philosophicus. Philosophical Investigations]. Kyiv: Osnovy, 1995.

Zelenskyj, V. (2019). Prezydent: Maiemo znaty nashu Konstytutsiiu, a holovnedotrymuvatys' i povazhaty (Video) [President: We Must Know Our Constitution, and Most Importantly, Abide by and Respect It]. Prezydent Ukrainy Volodymyr Zelenskyj. Ofitsiyne internet-predstavnytstvo. Accessed December 26, 2021. https:// www.president.gov.ua/news/prezident-mayemo-znati-nashu-konstituciyu-golovne-dotrimuvat-56o93.

Zelenskyj, V. (2020). Zvernennia Prezydenta Ukrainy z nahody Dnia Konstytutsii. [Appeal of the President of Ukraine on Constitution Day]. Prezydent Ukrainy Volodymyr Zelens'kyj. Ofitsijne internet-predstavnytstvo. Accessed: December 26, 2021. https://www.president.gov.ua/news/zvernennya-prezidenta-ukrayini-znagodi-dnya-konstituciyi-61937

Dr. Solomiia Kryvenko is an Assistant Professor at Ivan Franko National University of Lviv and Ukrainian Catholic University 


\title{
Символи в Українському Публічному Дискурсі (Аналіз Президентських Промов з Нагоди Дня Конституції)
}

\section{Соломія Кривенко}

Старший викладач

Львівський національний університет імені Івана Франка / Український католицький університет, Україна

\begin{abstract}
Анотація
Стаття присвячена розгляду символів як певного виду знаків, значення яких встановлюється домовленістю або звичкою. Один з підходів-що символи у публічному дискурсі є відображенням цінностей та анти-цінностей суспільства, які формуються у процесі масової комунікації. Ця стаття визначає основні ознаки, включно із емоційною залученістю, долученістю до конкретного акту комунікації та гарною поінформованістю. Визначаються типи значення і пояснюється механізм їх встановлення. Стаття звертається до концепції семантичного змагання. На думку М. Едельмана, значеннєві структури можна поділити на моно-, бі- та мультимодальні-залежно від кількості значень, присвоєних ключовим символам. Президентські промови на День Конституції України у 2017-2020 роках стали предметом аналізу цієї статті. Завдячуючи змістовному аналізу емоційно забарвлених слів, було ідентифіковано символи, характерні для промов П. Порошенка та В. Зеленського. Під час аналізу особлива увага зверталася на спільності та відмінності українських цінностей та анти-цінностей
\end{abstract}

Ключові слова: дискурс аналіз, публічний дискурс, символи, семантика, медіа аналітика, масові комунікаціїdiscourse analysis, public discourse, symbols, semantics, media analytics, mass communication. 